\title{
Korupsi dalam Perspektif Budaya Hukum
}

\author{
M.Syamsudin \\ Universitas Islam Indonesia, Yogyakarta
}

\begin{abstract}
In the perspective of legal culture corruption denotes a behavior that contradicts to values and norms either those of honesty, social, religion or the law. But, the emerging of the corruption itself is influenced by individual and collective need and demand, and also iit is supported by social culture environment that inherited the corruption tradition. Besides, legal culture of the government dose not justify law and pays priority over social status, economy, and that of politics of corruptor. The internal legal cultutre of law enforcement itself does not support to solve the corruption that shows the corruption in the process of court. Departing from this phenomenon it is clearly that corruption is regarded as society culture that difficult to solve, instead the corruption can be proved legally but it can be regarded as other meaning for instance commission, kompensation, reward, insentive, return fee and so on.
\end{abstract}

Kaywords: Corruption, Law Enforcement, Legal Culture

Tulisan ini berangkat dari keprihatinan dan
kegelisahan yang mendalam terhadap
masalah besar yang sedang dihadapi
bangsa Indonesia dewasa ini yaitu "korupsi".
Menurut Suharko (2005), ditinjau dari
berbagai segi seperti legal perundang-
undangan, kebijakan, dan institusi untuk
pemberantasan korupsi, Indonesia telah
memiliki kelengkapan yang memadai,
bahkan nyaris sempurna untuk melakukan
pemberantasan korupsi secara sistematis.
Indonesia telah memiliki TAP MPR Nomor
XI/MPR/ 1998 tentang Penyelenggaraan
Negara yang Bersih dan Bebas Korupsi,
Kolusi dan Nepotisme (KKN) dan UU No.
28 Tahun 1999 tentang Penyelenggaraan
Negara yang Bersih daan Bebas KKN. Dari
ketentuan itu lahir pula UU No. 31 Tahun
1999 Jo. UU No. 20 Tahun 2001 tentang
Pemberantasan Tindak Pidana Korupsi, UU
No. 30 Tahun 2002 tentang Komisi
Pemberantasan Tindak Pidana Korupsi ${ }^{1}$

yang di beberapa negara seperti Hongkong dan Singapura berhasil mengikis korupsi dan menjadi ujung tombak gerakan pemberantasan korupsi. Di lain pihak sudah ada beberapa peraturan pemerintah dengan operasinal pemberantasan korupsi. Jadi secara teoritis sebenarnya hampir tidak ada alasan bagi peningkatan dan perluasan praktik korupsi di Indonesia (Suharko, 2005).

Namun demikian, sejumlah fakta mutakhir menunjukkan tendensi yang sebaliknya, praktik korupsi semakin meluas, vulgar dan merajalela. Perkembangan praktek korupsi dari tahun ke tahun

\footnotetext{
${ }^{1}$ Meskipun menurut Putusan Mahkamah Konstitusi Republik Indonesia keberadaan Pengadilan TIPIKOR yang diatur berdasarkan Pasal 53 UU No. 30 Tahun 2003 dianggap inkonstitusional dan memberi kesempatan kepada pembentuk UU untuk membentuk UU Pengadilan Tipikor secara khusus.
} 
semakin meningkat, baik dari segi kuantitas atau jumlah kerugian keuangan negara maupun dari segi kualitas yang semakin sistematis, canggih serta lingkupnya sesudah semakin meluas dalam seluruh aspek masyarakat.

Berdasarkan laporan lembaga Transparansi Internasional (TI) yang selalu menerbitkan hasil survei Coruption Perception Index sejak tahun 1998, Indonesia selalu berada di deretan atas negara-negara terkorup di dunia. Pada tahun 1998, Indonesia pada peringkat ke- 6 setelah Kamerun, Paraguay, Honduras, Tanzania, dan Nigeria. Pada tahun 1999, Indonesia berada pada peringkat ke-3 setelah Kamerun dan Negria. Pada tahun 2000, Indonesia pada peringkat ke-5 setelah Negria, Yugoslavia, Ukraina dan Azarbaijan. Pada tahun 2001, Indonesia pada peringkat ke- 4 setelah Bangladesh, Nigeria, dan Uganda. Meskipun pada tahun 2004 nilai indeks persepsi korupsi (IPK) Indonesia mengalami peningkatan, yakni 1,9 menjadi 2,0 namun itu tidak signifikan karena tetap saja Indonesia menduduki posisi sebagai negara peringkat ke-5 terkorup dari 146 negara yang disurvei. Bahkan posisi itu sebenarnya lebih buruk dari tahun sebelumnya karena negara yang disurvei untuk tahun 2004 berjumlah lebih banyak (146 negara). Pada tahun 2003 Indonesia menduduki posisi ke- 6 terburuk dari 136 negara yang disurvei (Kompas, 2004).

Tingginya tingkat korupsi di Indonesia juga dicatat oleh Political Economy and Risk Consultancy Ltd. (PERC), sebuah lembaga independen yang berkedudukan di Hongkong yang memantau tingkat risiko investasi di negara-negara Asia. Dari tahun 1998 sampai 2000, Indonesia pada peringkat pertama Negara terkorup di Asia, dan pada tahun 2001 turun menjadi peringkat ke-2 setelah Vietnam dan pada Tahun 2005, menempati urutan pertama.
Dilihat dari segi penegakan hukum, penanganan kasus korupsi di Indonesia masih menunjukkan suatu yang mengecewakan masyarakat. Berdasarkan hasil survei yang dilakukan oleh Indonesia Corruption Watch (ICW) menunjukkan bahwa Pengadilan Umum dipersepsi publik sebagai lembaga yang masih berpihak pada pelaku korupsi. Selama tahun 2006, ICW mencatat terdapat 117 terdakwa korupsi yang diputus bebas oleh pengadilan Umum dari 362 terdakwa korupsi yang diajukan ke Pengadilan Negeri, Pengadilan Tinggi dan Mahkamah Agung. ${ }^{2}$

Kasus pembebasan pelaku korupsi terjadi di hampir semua pengadilan baik di pusat (Jakarta) maupun di daerah-daerah. Di daerah misalnya, bebasnya sebanyak 22 anggota Dewan Perwakilan Rakyat Daerah (DPRD) Bali dalam kasus korupsi Anggaran Pendapatan Belanja Daerah (APBD) Rp 57,1 milliar. Di Garut terdapat 16 mantan anggota DPRD Garut periode 1999-2004 dibebaskan setelah dinyatakan tidak bersalah dan tidak melawan hukum. Di Pengadilan Negeri Jakarta Selatan yang diputus bebas misalnya kasus korupsi kredit macet Bank Mandiri Rp 160 milliar dengan terdakwa mantan Dirut E.C.W. Neloe dan dua mantan direksi Bank Mandir, Kasus korupsi

\footnotetext{
${ }^{2} \mathrm{Hal}$ senada juga ditunjukkan oleh hasil survei Pusat Studi Kebijakan Publik (PSKP) Universitas Gadjah Mada (UGM) Yogyakarta bekerjasama dengan Kemitraan menunjukkan bahwa kepercayaan publik terhadap lembaga pemegang kekuasaan kehakiman rendah dan tidak percaya pada lembaga pengadilan, meskipun tidak spesifik pada pemberantasan korupsi. Responden terdiri dari Pegawai Negeri Sipil (PNS), anggota Dewan Perwakilan Rakyat Daerah (DPRD), Lembaga Swadaya Masyarakat (LSM), pengusaha, pegawai swasta, wartawan, dan dosen yang didata dari 10 provinsi di Indonesia;
} 
Korupsi dalam Perspektif Budaya Hukum ; M.Syamsudin

penyimpanan penggunaan dana Bulog $\mathrm{Rp}$ 169 milliar dengan terdakwa Nurdin Khalid; Kasus korupsi dana Jamsostek Rp1,8 milliar dengan terdakwa Muchtar Pakpahan. Lain halnya dengan kasus korupsi yang ditangani oleh Pengadilan Tindak Pidana Korupsi (Tipikor), belum ada pelaku korupsi yang diputus bebas (Jawa Pos, 2007).

Gambaran lemahnya perlakuan terhadap koruptor di Indonesia, juga ditunjukkan oleh banyaknya pelaku korupsi yang telah memadai menjadi terdakwa diputus bebas atau lepas dari jeratan hukum. Kalaupun sebagian dari mereka dipidana, akan tetapi jumlahnya relatif kecil dan sanksi yang dijatuhkan terhadap pelaku korupsi relatif sangat ringan, tidak sesuai dengan perbuatan yang dilakukan (Ronny, 2006). Fakta-fakta tersebut mengundang ketidakpuasan dan keraguan masyarakat terhadap kinerja pengadilan dalam menangani kasus korupsi (Kompas 2004).

Ketidakpercayaan masyarakat terhadap lembaga peradilan di Indonesia mengakibatkan merosotnya wibawa hukum dan lembaga peradilan dewasa ini. Bahkan isu korupsi juga sudah memasuki lembaga peradilan itu sendiri. Berdasarkan laporan tentang Bureaucratic and JudiciaryBribery yang pernah dibuat oleh Daniel Kaufmann pada tahun 1998 dinyatakan bahwa penyuapan di Peradilan Indonesia adalah yang paling tinggi di negara-negara seperti Ukraina, Venezuela, Rusia, Kolombia, Mesir, Yordania, Turki, dan lain-lain (Lubis, 1998).

Beberapa isu yang mengindikasikan terjadinya praktek Korupsi Kolusi Nepotisme (KKN) di lembaga peradilan pernah diungkapkan antara lain oleh Adi Andojo Soetjipto yang membongkar kasus kolusi di Mahkamah Agung dalam kasus Gandhi Memorial School (Yasonna, 1996). Ditambahkan pula dugaan KKN dua orang Hakim Agung yang masih aktif dan seorang Hakim Agung purna tugas yang disangka telah menerima suap bernilai puluhan juta rupiah berdasarkan laporan yang masuk dari saksi pelapor sebagai korbannya (Erman, 2006).

\section{Batasan Pengertian Korupsi}

Secara umum korupsi didefinisikan sebagai penyalahgunaan kekuasaan untuk kepentingan pribadi. Robert Klitgaard (2002), merumuskan pengertian umum korupsi dalam rumus:

$$
\mathrm{C}=\mathrm{M}+\mathrm{D}-\mathrm{A}
$$

Dari rumus tersebut dapat dijelaskan bahwa, Korupsi ( $\mathrm{C}=$ Corruption) adalah fungsi dari Monopoli ( $\mathrm{M}=$ Monopoly) ditambah kewenangan ( $\mathrm{D}=$ Discretion) dikurangi Akuntabilitas ( $\mathrm{A}=$ Acuntability). Jadi korupsi dapat terjadi apabila ada monopoli kekuasaan di tengah ketidakjelasan aturan dan kewenangan, akan tetapi tidak ada mekanisme akuntabilitas atau pertanggungjawaban kepada publik (Robert, 2002).

William J.Chambliss, mengemukakan bahwa dalam korupsi terlibat banyak pihak yang disebutnya sebagai cabalatau jejaring korupsi. la melihat bahwa korupsi merupakan bagian integral dari setiap birokrasi yang bertemu dengan kepentingan segelintir pengusaha, penegak hukum, dan politisi yang sulit dibongkar. Jejaring korupsi itu melibatkan para elit di pusat kekuasaan: pucuk pimpinan eksekutif, elit partai politik, petinggi lembaga peradilan dan kalangan bisnis. Korupsi merupakan bagian dari sistem itu sendiri, oleh karena itu bukan pekerjaan mudah untuk memberantas korupsi karena aparat penegak hukum sering berada pada situasi yang dilematis. Korupsi bukanlah kejahatan di luar sistem, oleh karena itu jejaring korupsi sangat sulit diterobos dari dalam karena kolusi antara 
pengusaha dengan politisi dan aparat penegak hukum. Jejaring korupsi juga sulit diterobos dari luar, karena aparat penegak hukum dapat menyediakan penjahat kelas teri yang siap dikorbankan untuk melindungi pelaku sesungguhnya yang berada dalam jejaring tersebut (William, 2002).

Paul Heywood (1977), mendefinisikan korupsi politik dengan penekanan pada ruang publik sebagai "corrupt activities which takeplace either wholly within the public sphare or at interface between the public and private spare -such as when politicians or functianories use their privileged acces to resources (in whatever form) illigetimately to benefit themselves or others". Dari batasan tersebut korupsi politik dibatasi oleh kriteria pelaku, yaitu politisi. Termasuk kategori politisi adalah pejabat publik, seperti pemimpin birokrasi, pemimpin peradilan dan komandan polisi. Dengan demikian korupsi di sektor bisnis atau korupsi keuangan ( $f i-$ nancial corruption) seperti manipulasi laporan keuangan, manipulasi audit, tidak termasuk kategori korupsi politik. Kecuali aktivitas korupsi tersebut melibatkan pejabat publik (Paul, 1977).

Syed Husein Alatas (1987), berdasarkan hasil penelitiannya di Asia, terutama di Malaysia dan Indonesia mengemukakan tujuh kategori korupsi, yaitu: (1) Korupsi transaktif yaitu uang yang menunjukkan adanya kesepakatan timbal balik antara pihak yang memberi dan menerima keuntungan bersama. Kedua pihak samasama aktif dalam menjalankan perbuatan tersebut; (2) Korupsi pemerasan yaitu jenis korupsi dimana pihak pemberi dipaksa untuk menyuap demi mencegah kerugian yang mengancam dirinya, kepentingannya, atau orang-orang dan hal-hal yang dihargainya. Korupsi yang dilakukan oleh Polisi lalu lintas termasuk jenis korupsi pemerasan; (3) Korupsi investif yaitu pemberian barang atau jasa tanpa ada pertalian langsung dengan keuntungan tertentu, selain keuntungan yang diharapkan akan diperoleh pada masa mendatang. Bentuk korupsi seperti ini dilakukan oleh yang memberi uang bulanan secara rutin kepada hakim. Harapannya kelak ketika kasusnya masuk ke pengadilan, hakim yang telah digajinya langsung menangani perkaranya; (4) Korupsi perkerabatan (nepotisme) yaitu penunjukan secara tidak sah terhadap teman atau saudara untuk memegang suatu jabatan, atau tindakan pengutamaan dalam segala bentuk yang bertentangan dengan norma atau peraturan yang berlaku; (5) Korupsi defensif. Korupsi ini dilakukan oleh korban korupsi pemerasan. Dengan demikian orang yang diperas melakukan korupsi untuk menyelamatkan kepentingannya. Korupsi seperti ini sering dilakukan oleh keluarga terdakwa yang tidak ingin terdakwa ditahan atau diproses lebih lanjut; (6) Korupsi otogenik yaitu korupsi yang dilakukan oleh seorang diri karena mempunyai kesempatan untuk memperoleh keuntungan dari sesuatu yang diketahuinya sendiri. Panitera pengadilan kerap melakukan korupsi seperti ini dalam administrasi pendaftaran perkara. Ketidakjelasan tarif pendaftaran membuatnya leluasa menentukan harga yang harus dibayar oleh pengacara; (7) Korupsi dukungan yaitu dukungan terhadap korupsi yang ada atau penciptaan suasana yang kondusif untuk dilakukaknnya korupsi. Korupsi ini dilakukan oleh elit di lembaga peradilan yang tidak mempunyai kemauan politik untuk menindak tegas bawahannya (Hussein, 1987).

Fatwa Ulama Nahdlatul Ulama (NU) pada Munas Alim Ulama dari kalangan NU di Asrama Haji Pondok Gede, Agustus 2002 mengemukakan hal-hal sebagai berikut : (1) Dalam pandangan syariat, korupsi merupakan penghianatan berat (ghulul) terhadap 
Korupsi dalam Perspektif Budaya Hukum ; M.Syamsudin

amanat rakyat. Dilihat dari cara kerja dan dampaknya, korupsi dapat dikategorikan sebagai pencurian (sariqah), perampokan (nahb); (2) Pengembalian uang korupsi tidak menggugurkan hukuman. Karena tuntutan hukuman merupakan hak Allah, sementara pengembalian uang korupsi ke negara merupakan hak masyarakat (hak adamiy). Hukuman yang layak untuk koruptor adalah potong tangan sampai dengan hukuman mati; (3) Money politics sebagai pemberian (berupa uang atau benda lain) untuk mempengaruhi dan atau menyelewengkan keputusan yang adil dan obyektif dalam pandangan syariat merupakan suap (risywah) yang dilaknat Allah, baik yang memberi (rasyı), yang menerima (murtasyi), maupun yang menjadi perantara (raaisyi) (Gatra, 2002).

\section{Faktor Penyebab Korupsi}

Selo Sumardjan mengatakan bahwa korupsi, kolusi dan nepotisme adalah dalam satu nafas karena ketiganya melanggar kaidah-kaidah kejujuran dan norma hukum. Adapaun faktor sosial pendukung KKN adalah : (1) Desintegrasi (anomie) sosial karena perubahan sosial terlalu cepat sejak revolusi nasional, dan melemahnya batas milik negara dan milik pribadi; (2) Fokus budaya bergeser, nilai utama orientasi sosial beralih menjadi orientasi harta, kaya tanpa harta (sugih tanpo bondho) menjadi kaya dengan harta; (3) Pembangunan ekonomi menjadi panglima pembangunan bukan pembangunan sosial atau budaya; (4) Penyalahgunan kekuasaan negara sebagai short cut mengumpulkan harta; (5) Paternalisme, korupsi tingkat tinggi, menurun, menyebar, meresap dalam kehidupan masyarakat. Bodoh kalau tidak menggunakan kesempatan menjadi kaya (aji mumpung); (6) Pranata-pranata sosial kontrol tidak efektif lagi.
Evi Hartanti menyebutkan faktor-faktor penyebab terjadinya korupsi dikarenakan lemahnya pendidikan agama dan etika, kolonialisme, kurangnya pendidikan, kemiskinan, tidak adanya sanksi yang keras, kelangkaan lingkungan yang subur untuk pelaku anti korupsi, struktur pemerintahan, perubahan radikal, dan keadaan masyarakat. Namun demikian faktor yang paling penting dalam dinamika korupsi adalah keadaan moral dan intelektual para pemimpin masyarakat (Hartanti, 2006).

Menurut Luhut M. Pangaribuan (2002), perilaku koruptif yang terjadi pada hampir semua penegak hukum, bukan karena moral yang rendah namun sebagai akibat terjadinya demoralisasi dari para penegak hukum itu sendiri. Akibatnya, menerima uang secara tidak halal, menurut persepsi mereka, bukanlah sesuatu yang aneh lagi, akan tetapi menjadi suatu keharusan untuk mereka lakukan. Setidaknya terdapat empat hal faktor penyebab yang dapat dikemukakan dari perilaku koruptif dari para penegak hukum yaitu : (1) Kesejahteraan atau gaji rendah, akan tetapi life style-nya tinggi; (2) Adanya ketidakpercayaan timbal balik di antara penegak hukum itu sendiri; (3) Akibat pola korupsi yang terjadi pada masa Orde Baru; (4) Tidak adanya standar profesi bagi advokat (Luhut, 2002).

Berdasarkan rekomendasi para pakar hukum Center for The Independence of Judge and Lawyer (CIJL) pada konferensi dua tahunan (17-22 September 2000) di Amsterdam, disimpulkan bahwa judicial coruption terjadi karena tindakan-tindakan yang menyebabkan ketidakmandirian lembaga peradilan dan institusi hukum (polisi, jaksa, advokat dan hakim). Khususnya jika hakim atau pengadilan mencari atau menerima berbagai macam keuntungan atau janji berdasarkan 
penyalahgunaan kekuasaan kehakiman atau perbuatan lainnya, seperti suap, pemalsuan, penghilangan data atau berkas pengadilan, perubahan dengan sengaja berkas pengadilan, pemanfaatan kepentingan umum untuk kepentingan pribadi, sikap tunduk kepada campur tangan luar dalam memutuskan perkara karena adanya tekanan, ancaman, nepotisme, conflict of interest, kompromi dengan pembela advocat), pertimbangan keliru dalam mutasi, promosi dan pensiun, prasangka memperlambat proses peradilan, dan tunduk kepada kemauan pemerintah dan partai politik (Putu, 2001).

Akibat adanya korupsi di pengadilan, maka sudah dapat dipastikan sebagaian besar atau bahkan seluruhnya, produk lembaga peradilan tidak mencerminkan rasa keadilan dan kepastian hukum, karena disinyalir terjadi "main mata" di antara aparat penegak hukum dengan para pihak pencari keadilan. Permainan seperti itu semakin memperburuk bahkan mempercepat proses pembusukan lembaga peradilan yang pada gilirannya akan menumbuhkan sikap antipati kepercayaan masyarakat kepada lembaga peradilan. Kemudian yang terjadi adalah munculnya serta tumbuh suburnya berbagai tindakan main hakim sendiri di masyarakat dalam menyelesaikan sengketa.

\section{Perspektif Budaya Hukum}

Istilah budaya hukum pertama-tama dikemukakan oleh Friedman untuk menyebut kekuatan-kekuatan sosial (social forces) yang mempengaruhi bekerjanya hukum di masyarakat, yang berupa elemenelemen nilai dan sikap masyarakat berhubungan dengan institusi hukum. Dikemukakan oleh Friedman bahwa:

Social forces are constantly at work on the law-destroying here, renewing there; inigorating here, deadening there; choosing what parts of "law" will oprerate, which part will not, what subtitute, detours, and bypasses will spring up; what changes will take place openly or secretly. For want of a better term, we can call some of these forces the legal culture. It is the element of social attitude and value (Lawrence, 1975).

Lebih lanjut dikemukakan bahwa istilah budaya hukum mengacu pada pengetahuan publik, sikap dan pola perilaku masyarakat berkaitan dengan sistem hukum.

The term legal culture has been loosly used to discribe a number of related phenomena. It refers to public knowlege of and attitudes and behavior patterns toward the legal system. Do people feel and act as if courts are fair? When are they willing to use courts? What part of the law do they consider legitimate? What do they know about the law in general ? These attitudes differ from person to person, but one can also speak of the legal culture of a country or a group, if there are patterns that distinguish it from the culture of the countries or groups (Lawrence, 1975).

Friedman, menelaah budaya hukum dari pelbagai perspektif. la menganalisa budaya hukum nasional yang dibedakan dari sub-budaya hukum yang berpengaruh secara positif atau negatif terhadap hukum nasional. la juga membedakan budaya hukum internal dan budaya hukum eksternal. Budaya hukum internal merupakan budaya hukum warga masyarakat yang melaksanakan tugastugas hukum secara khusus, seperti polisi, jaksa hakim dalam menjalankan tugasnya, sedangkan budaya hukum eksternal merupakan budaya hukum masyarakat pada umumnya, misalnya bagaimana sikap dan pengetahuan masyarakat terhadap ketentuan perpajakan, perceraian dan 
Korupsi dalam Perspektif Budaya Hukum ; M.Syamsudin

sebagainya. la juga membedakan budaya hukum tradisional dan budaya hukum modern. Dengan adanya pelbagai sistem hukum dalam suatu komunitas politik tunggal maka disebut pluralisme hukum. Pluralisme hukum dapat berbentuk horizontal atau vertikal. Pada yang horisontal masingmasing subsistem atau sub-budaya mempunyai kekuatan hukum sama, sedangkan yang vertikal kekuatan hukumnya berbeda-beda.

Menurut Friedman, budaya hukum menunjuk pada dua hal yaitu : (1) unsur adatistiadat yang organis berkaitan dengan kebudayaan secara menyeluruh; dan (2) unsur nilai dan sikap sosial. Lebih lanjut dikatakan bahwa sistem hukum yang terdiri dari struktur dan subtansi, bukanlah merupakan mesin yang bekerja. Apabila kedua unsur itu berfungsi dalam masukan dan keluaran proses hukum, maka kekuatan-kekuatan sosial tertentu berpengaruh terhadapnya. Kekuatankekuatan sosial itu merupakan variabel tersendiri yang disebut 'budaya hukum'. Variabel itu berproses bersamaan dengan kebudayaan sebagai suatu variasi, yang kemungkinan variabel tersebut menentang, melemahkan, atau memperkuat sistem hukum (Lawrence, 1975).

Friedman melihat bahwa hukum itu tidak layak hanya dibicarakan dari segi struktur dan subtansinya saja, melainkan juga dari segi unsur tuntutan-tuntutan (demands) yang berasal dari kepentingankepentingan (interests) individu dan kelompok masyarakat ketika berhadapan dengan institusi hukum. Kepentingankepentingan dan tuntutan-tuntutan tersebut merupakan kekuatan-kekuatan sosial (social forces) yang tercemin dalam sikap dan nilai-nilai yang ada di masyarakat. Unsur kekuatan-kekuatan sosial tersebut disebut oleh Friedman sebagai budaya hukum (le- gal culture) (Satjipto, 1980). Tuntutantuntutan tersebut datangnya dari masyarakat atau para pemakai jasa hukum dan menghendaki suatu penyelesaian atau pemilihan cara-cara penyelesaian dari alternatif-alternatif penyelesaian. Pemilihan tersebut akan didasarkan pada pengaruh faktor orientasi, pandangan, perasaan, sikap dan perilaku seseorang dalam masyarakat terhadap hukum. Faktor-faktor tersebut didasarkan pada besarnya pengaruh dorongan kepentingan, ide, sikap, keinginan, harapan, dan pendapat orang tentang hukum. Jika ia memilih pengadilan, hal tersebut disebabkan karena yang bersangkutan mempunyai persepsi positif tentang pengadilan dan dipengaruhi oleh faktor-faktor pendorong tersebut (Satjipto, 1991).

Jika konsep budaya hukum ini dipergunakan untuk melihat penanganan korupsi, maka akan nampak bahwa makna korupsi itu sendiri akan sangat ditentukan oleh nilai-nilai yang ada dibalik korupsi itu sendiri. Dari berbagai pengertian korupsi yang telah dikemukakan di muka, nampak bahwa korupsi merupakan suatu perbuatan yang bertentangan dengan nilai-nilai dan norma-norma kejujuran, sosial, agama dan hukum. Namun demikian munculnya korupsi itu sendiri sangat dipengaruhi oleh tuntutan-tuntutan kebutuhan individual maupun kelompok serta didukung oleh lingkungan sosial-budaya yang mewarisi tradisi korup. Di samping itu budaya hukum elit penguasa tidak menghargai kedaulatan hukum, akan tetapi lebih mementingkan status sosial, ekonomi dan politik para koruptor. Budaya hukum internal penegakan hukum sendiri juga tidak mendukung pemberantasan korupsi, yang ditunjukkan dengan adanya praktek korupsi dalam proses peradilan (judicial corruption). 
Berdasarkan hasil penelitan yang pernah dilakukan oleh Wasingatu Zakiyah dkk, korupsi juga terjadi di seluruh lembaga peradilan, mulai dari Pengadilan Negeri sampai Mahkamah Agung. Korupsi tersebut melibatkan hampir seluruh pelaku di peradilan seperti hakim, jaksa, polisi, pengacara dan panitera. Selain itu pihak luar peradilan juga menjadi bagian dari praktek korupsi seperti calo perkara. Karena korupsi terjadi secara meluas di pengadilan, publik lalu menjulukinya dengan istilah mafia peradilan. Mafia peradilan lebih berkonotasi pada praktek korupsi antara hakim, pengacara, dan jaksa, serta pihakpihak lain di peradilan, yaitu merujuk pada konspirasi untuk memenangkan salah satu pihak tertentu.

Karena bertahun-tahun praktek korupsi dibiarkan, akhirnya korupsi peradilan menjadi sistemik. Disebut demikian karena mafia peradilan menjadi bagian dari sistem peradilan itu sendiri. Praktek mafia peradilan seakan-akan menjadi sebuah kebiasaan yang wajar dan natural di lingkungan peradilan. Calo-calo perkara di peradilan aman beroperasi di depan hakim, panitera, jaksa dan polisi. Hasil penelitian tersebut berhasil mengungkap bahwa sekitar 300 responden yang menjadi sumber data penelitian, mengakui terjadinya korupsi di pengadilan.

Berdasarkan temuan pola-pola korupsi, mafia peradilan terjadi pada setiap tahapan beracara, baik pada peradilan perdata, pidana dan niaga. Pada tahap penyelidikan dan penyidikan dalam peradilan pidana, sebagai contoh, jikalau ada uang, tersangka tidak harus mendekam di tahanan. Bahkan kalau negosiasi lancar, tersangka dapat bebas begitu saja. Hal yang sama juga terjadi di Kejaksaan.Pasal-pasal meringankan yang dikenakan dalam tuntutan jaksa dianggap sebagai sebuah kebaikan yang harus dihargai dengan uang. Demikian di kalangan hakim, vonis yang dijatuhkan bisa ditawar dengan imbalan uang dan fasilitas (Zakiyah, 2002).

Dari penglihatan inilah, maka nampak bahwa ada sebagian kalangan yang berpendapat bahwa korupsi sudah menjadi budaya bagi masyarakat Indonesia (Sutandiyo, 2000). Korupsi hampir terjadi di setiap tingkatan dan aspek kehidupan masyarakat, mulai dari mengurus ljin Mendirikan Bangunan (IMB), proyek pengadaan di instansi-instansi pemerintah sampai proses penegakan hukum. Tanpa disadari, korupsi muncul dari kebiasaan yang dianggap lumrah dan wajar oleh masyarakat umum, seperti memberi hadiah kepada pejabat/ pegawai negeri atau keluarganya sebagai imbal jasa sebuah pelayanan. Kebiasaan itu dipandang lumrah dilakukan sebagai bagian dari budaya ketimuran. Kebiasaan ini lama-lama menjadi bibit-bibit korupsi yang nyata (KPK, 2006). Praktik korupsi sudah sedemikian hebatnya mewarnai keseharian bangsa Indonesia. Dalam ungkapan M. Hatta, korupsi pada situasi yang demikian sudah dianggap sebagai budaya bangsa (Sahlan, 2005).

Dalam perspektif demikian, kalaupun pada akhirnya dapat dibuktikan legalitasnya, korupsi sebenarnya bukanlah korupsi, melainkan mempunyai makna lain seperti komisi, kompensasi, hadiah, insentif, return fee, tali asih, asuransi, jasa keringat, dan istilah-istilah lain yang berkonotasi serupa (Sugiharto, 2005).

Menurut pengalaman Sahlan Said (mantan hakim), ia sering menyaksikan perilaku judicial corruption itu dilakukan oleh rekan-rekan seprofesinya, terutama terhadap kasus-kasus yang dianggap "basah" seperti kasus korupsi. Misalnya pada waktu menangani kasus korupsi di Banyumas, di mana terdakwa adalah seorang pemborong yang disinyalir kasus 
Korupsi dalam Perspektif Budaya Hukum ; M.Syamsudin

ini melibatlan pejabat-pejabat daerah. Putusan majelis hakim pada waktu itu membebaskan terdakwa, tetapi ia sebagai salah satu anggota majelis berbeda pendapat dengan 2 hakim lainnya, karena menurutnya terdakwa terbukti melakukan tindak pidana korupsi. Putusan tersebut sempat membuat berang Jaksa Penuntut Umum (JPU) yang mengindikasikan adanya KKN. Setelah timbul kontroversi, 2 hakim tersebut diperiksa oleh Ketua Pengadilan Tinggi Semarang (Sahlan, 2005).

Kasus lainnya adalah perkara korupsi Jogja Expo Center (JEC) yang terdakwanya adalah seorang anggota Dewan Perwakilan Rakyat Daerah (DPRD) Tingkat I Yogyakarta. Majelis hakim menyatakan bahwa terdakwa terbukti bersalah melakukan korupsi dengan cara menyalahgunakan jabatannya untuk meminta uang Tunjangan Hari raya (THR). Pada kasus ini terdapat perlakuan diskriminatif yakni beberapa orang yang mestinya berpotensi untuk menjadi terdakwa ternyata tidak diajukan ke pengadilan, sehingga terkesan hanya ada 1 terdakwa "martil" yang diajukan ke pengadilan pada kasus yang sarat dengan muatan politis tersebut. Pada waktu itu Kejaksaan Tinggi menyatakan tidak ada terdakwa lain. Padahal sebelumnya sudah ada beberapa nama yang disidik dan tidak pernah dikeluarkan SP3 (Surat Perintah Penghentian Penyidikan) oleh jaksa (Sahlan, 2005).

Menurut Yosanna H.Laoly, bagi sebagian besar praktisi hukum, dugaan adanya kolusi bahkan korupsi di lingkungan peradilan bukan suatu yang aneh atau mengejutkan. Sudah bukan rahasia lagi di kalangan pengacara, mereka tidak hanya bergantung pada logika hukum saja untuk memenangkan perkara, akan tetapi juga bergantung pada pendekatan-pendekatan non-hukum. Pendekatan-pendekatan ini justru dianggap lebih penting (Yasona, 1996). Kasus pemalsuan putusan Mahkamah Agung juga menjadi bukti adanya praktek KKN di lingkungan peradilan. Bukti konkrit KKN yang terjadi di lembaga peradilan yang dilakukan oleh hakim terjadi pada saat akhir tahun 1970-an hingga awal tahun 1980-an ketika digelar operasi tertib pusat (obtibpus). Pada saat itu banyak hakim yang kena jaring operasi karena tertangkap basah menerima uang suap di kantornya (Yasona, 1996). Ada juga kasus seorang hakim meminta uang suap kepada seorang nyonya sebesar 50 juta rupiah untuk memenangkan perkaranya (Husein, 1987). Bahkan pada dekade itu pernah ada seorang hakim pria senior yang karena terbukti meminta dan menerima uang suap, akhirnya hakim tersebut diadili dan dijatuhi pidana penjara serta diberhentikan dengan tidak hormat dari jabatannya sebagai hakim.

\section{Solusi: Dibutuhkan Penegak Hukum Progresif}

Keterpurukan penegakan hukum dalam menangani masalah korupsi yang digambarkan di atas pada puncaknya telah membawa bangsa Indonesia terjatuh pada keadaan krisis hukum. Krisis adalah keadaan tidak normal oleh karena berbagai institusi yang telah dinormakan untuk menata prosesproses dalam masyarakat tidak mampu lagi menjalankan fungsinya secara tepat. Hukum kehilangan kepercayaan dan pamor untuk mewujudkan nilai keadilan yang harus diberikan. la tidak lagi berada pada posisi otoritatif untuk menata dan mengendalikan proses-proses ekonomi, sosial, politik dsb, melainkan difungsikan sebagai alat untuk kepentingan kekuasaan. Hukum tidak lagi bekerja secara otentik. Dampak dari ketidakpercayaan pada penegakan hukum tersebut, sebagian rakyat kemudian melakukan tindakan penyelesaian sendiri, yang salah satu bentuknya adalah perbuatan 
main hakim sendiri (eigenrichting). Situasi sosial menjadi anomis dan setiap orang bebas membuat tafsiran, melakukan dan memutuskan tindakan sendiri. Satjipto Rahardjo menggambarkan sistuasi ini sebagai Era Hukum Rakyat (Satjipto, 2002).

Dalam situasi krisis atau tidak normal ini dibutuhkan pula cara-cara penyelesaian hukum yang tidak normal atau cara yang di luar kebiasaan (extra-ordinary) akan tetapi masih dalam koridor atau kerangka dari tujuan hukum tersebut. Cara yang luar biasa ini bukan berarti bertindak anarkis, akan tetapi berwatak progresif. Berpikir luar biasa pada intinya adalah tidak membaca undang-undang seperti orang mengeja sebuah teks, akan tetapi mencari dan mengungkap makna dari undang-undang tersebut. Akibat mencari makna itu, lalu berani bertindak rule-breaking. Berpikir luar biasa ini harus dimulai dari kalangan komunitas hukum seperti hakim, jaksa, advokat, polisi dan akademisi (Satjipto, 2006).

Rule-breaking membutuhkan berbagai pendekatan cara penyelesaian hukum yang holistik dan bahkan ekstra legal untuk menggali makna hukum. Pengalaman penyelesaian hukum yang hanya mengandalkan pendekatan yuridis-formal yang bersifat linier hanya menambah deretan kekecewaan para pencari keadilan. Sudah saatnya para akademisi dan praktisi hukum berani mentransformasikan diri untuk mencari pendekatan dan cara berpikir alternatif untuk menyelesaikan berbagai persoalan hukum yang kian rumit dan kompleks. Berbagai pendekatan yang ada bukan saatnya lagi dipertentangkan dan dipersalahkan, akan tetapi justru saling melengkapi kekurangankekurangan yang ada dengan kelebihan masing-masing. Para lawyer harus bersikap terbuka dengan perkembangan yang terjadi dan tak perlu menutup diri. Bukankah ilmu pengetahuan itu dinamis dan tak pernah berhenti dengan inovasi-inovasi (Satjipto, 2006).

Terhadap hal yang demikian juga telah banyak pikiran dan pendapat dari para ahli tentang bagaimana jalan memperbaikinya. Di antara banyak pikiran dan pendapat yang berkembang itu antara lain berkaitan dengan ketidakmandirian serta merosotnya martabat pribadi dari para hakim. Oleh karena itu yang harus diperbaiki adalah kemandirian serta pribadi para hakimnya. Penegak hukum, terutama hakim harus berpikiran progresif (Kompas, 2002) dan berani menafsirkan atau menemukan hukum agar mampu menjawab semua persoalan yang datang ke hadapan para hakim sehingga putusan yang dihasilkan memenuhi rasa keadilan masyarakat (Charles, 2006).

\section{Daftar Pustaka}

Azizy, Q. 2006. "Menggagas IImu Hukum Indonesia", dalam Buku: Menggagas Hukum Progressif Indonesia, Penyunting : Ahmad Gunawan dan Muammar Ramadhan, Yogyakarta: Pusataka Pelajar;

Alatas, S.H. 1987. Korupsi: Sifat, Sebab, dan Fungsi. Jakarta : LP3ES;

Chambliss, W.J. t.t. Corruption, Bureaucracy and Power, in Chambliss (ed). Sociologcal Reading in the comflict perspective;

Friedman, L. M. 1975. The Legal System : A Social Science Perspektive, New York : Russel Sage Fondation;

Firdaus, M.Y. 2007. "Pandemik Korupsi dan Mentalitas Birokrasi”. Opini Radar Jogja, 27 Januari 2007; 
Korupsi dalam Perspektif Budaya Hukum ; M.Syamsudin

Gunawan, A\& R, Muammar (Ed). Menggagas Hukum Progresif Indonesia. Yogyakarta: Pustaka Pelajar;

Hartanti, E. 2006. Tindak Pidana Korupsi. Jakarta : Sinar Grafika

Heywood, P. 1977. "Political Corruption: Poblem and Perspectives" Political Studies, Vol.45 No.3, Special Issue;

Himawan, C. 2006. Hukum sebagai Panglima. Editor Abu Sunda. Jakarta: Kompas.

Klitgaard, R. 2002. Penuntun Pemberantasan Korupsi dalam Pemerintah Daerah. Terj. Masri Maris. Jakarta : YOI.

Laoly, Y. H. 1996. "Kolusi: Fenomene atau Penyakit Koronis", dalam Aldentua Siringoringo dan Tumpal Sihite, (Ed). Menyingkap Kabut Peradilanperadilan Kita -Menyoal Kolusi di Mahkamah Agung. Jakarta: Pustaka Forum Adil Sejahtera;

Lev, D. S. 1990. Hukum dan Politik di Indonesia, Kesinambungan dan Perubahan, terjemahan Nirwono dan AE Priyono, Jakarta : LP3ES;

Lubis, T. M. 1998. "Reformasi Hukum Anti Korupsi" Makalah disampaikan dalam Konferensi Menuju Indonesia yang Bebas Korupsi, Depok, September 1998;

Nitibaskara, Tb.R. R. 2006. Tegakkan Hukum Gunakan Hukum. Jakarta : Kompas;

Nirwono dan Priyono, AE.(ed). 1990. Hukum dan Politik di Indonesia,
Kesinambungan dan Perubahan, Jakarta : LP3ES.

Puspokusumo, RM.T. 1999. "Fungsi Ombudsman dalam Negara Demokrasi", Makalah pada Seminar tentang Fungsi Ombudsman dalam Negara Demokrasi, BPHN, 23-24 Agustus 1999;

Putra, H.S. A. 2002. "Korupsi di Indonesia: Budaya atau Politik Makna" dalam Wacana, Insis Press, Edisi 14, Tahun III,

Rahardjo, S.2006. Membedah Hukum Progresif. Joni Emirzon, dkk (ed). Jakarta : Kompas:

.2006. "Pemberantasan Korupsi Progresif". Makalah disampaikan pada diskusi Peran Komisi Yudisial dalam Pemberantasan Mafia Peradilan di Indonesia. FH Unissula / Kp2KKN Semarang 1 Pebruari, 2006;

. 2006. "Hukum Progresif, Kesinambungan, Merobohkan, dan Membangun", Jurnal Hukum Progresif Volume: 2 Nomor 1/April 2006;

. "Hukum Progresif sebagai Dasar Pembangunan Ilmu Hukum Indonesia". Dalam Buku : Menggagas Hukum Progressif Indonesia, Penyunting : Ahmad Gunawan dan Muammar Ramadhan, Pusataka Pelajar, Yogyakarta; 1991. IImu Hukum, Cetakan III, Bandung : PT Citra Aditya Bakti; 
UNISIA, Vol. XXX No. 64 Juni 2007

2003. "Budaya Hukum Indonesia" dalam Sisi-sisi lain dari Hukum di Indonesia. Karolus Kopong Medan dan Frans J. Rengka (Ed). Jakarta : Penerbit Kompas;

Said, S. 2005. "Penegakan Hukum Anti Korupsi”. Jurnal Demokrasi, Volume II/N0.7/Januari 2005;

Siringoringo, A dan Sihite, T.(tt) (Ed). Menyingkap Kabut Peradilanperadilan Kita -Menyoal Kolusi di Mahkamah Agung. Jakarta : Pustaka Forum Adil Sejahtera;

Suparman, E. 2006. "Asal Usul serta Landasan Pengembangan IImu Hukum Indonesia", dalam buku : Menggagas Hukum Progressif Indonesia, Penyunting : Ahmad Gunawan dan Muammar Ramadhan. Yogyakarta : Pustaka Pelajar;

Sugiharto, T. 2005. "Mengebor Sumur Tanpa Dasar" Jurnal Demokrasi, Volume II/ N0.7/Januari 2005.

Soekanto, S. et. al. 1994. Antropologi Hukum, Proses Pengembangan IImu Hukum Adat, Jakarta : CV Rajawali;
Suharko. 2005. "Pemberantasan Korupsi, Menuju Grand Strategy Anti Korupsi untuk Indonesia" Jurnal Demokrasi, Volume II/N0.7/Januari 2005;

Zakiyah, W, et.all. 2002. Menyingkap Tabir Mafia Peradilan. Jakarta : ICW;

Wignjosoebroto, S. Kompas, 4 September 2000.

Jawa Pos, 8 Januari 2007;

Jawa Pos, 19 Pebruari 2007;

Radar Jogja, 27 Januari 2007;

Kompas, 15 Juli 2002;

Kompas, 12 Nopember 2002;

Kompas, 28 April 2003;

Kompas, 12 Pebruari 2004;

Kompas, 3 Pebruari 2004;

Gatra, 10 Agustus 2002; 